\title{
Michał Sobczak Skuteczność Narodowego Programu Mieszkaniowego w zakresie społecznej polityki mieszkaniowej
}

The effectiveness of the National Housing Programme in the field of social housing policy

In the first 20 years of the 21st century, the social housing policy in Poland underwent many changes. They resulted from the lack of consistency in this respect and low patience of the ruling parties, which led to profound modifications in the approach to the housing policy practically with every new government. Until the implementation of the National Housing Programme (NHP), the housing policy in Poland was characterised by fragmented solutions, without any comprehensive approach to the issue in question. The aim of the article is to verify the effectiveness of the NHP, especially in terms of its social part, i.e., Mieszkanie Plus [Apartment Plus] package. The programme was described using the framework of theoretical assumptions of the social housing policy and the implementation of this policy in Poland after the year 2000. The author claims that the NHP is the first housing policy in Poland which applies a holistic approach and moves away from the practice of short-term, fragmented solutions. He recommends that those who are in power should exercise patience and refrain from introducing alterations after a very short period from the point of view of investment processes, as the implementation of such a complex housing policy as the NHP is planned for many years.

\begin{tabular}{r|l}
\hline DOI & https://doi.org/10.31268/StudiaBAS.2021.19 \\
\hline Słowa kluczowe & $\begin{array}{l}\text { polityka mieszkaniowa w Polsce, Narodowy Program Mieszkaniowy, } \\
\text { Mieszkanie Plus }\end{array}$ \\
\hline O autorze & $\begin{array}{l}\text { housing policy in Poland, National Housing Programme, Apartment } \\
\text { Plus }\end{array}$ \\
\hline $\begin{array}{l}\text { doktor nauk ekonomicznych, adiunkt w Katedrze Inwestycji } \\
\text { i Nieruchomości, Instytut Gospodarki Przestrzennej, Wydział } \\
\text { Ekonomiczno-Socjologiczny, Uniwersytet Łódzki • } \\
\text { michal.sobczak@uni.lodz.pl • ORCID 0000-0001-8297-4770 }\end{array}$ \\
\hline
\end{tabular}

Artykuł został udostępniony na licencji Creative Commons - Uznanie Autorstwa 3.0 Polska (CC BY 3.0 PL).

\section{Wstęp}

Społeczna polityka mieszkaniowa ulegała w Polsce licznym przeobrażeniom w pierwszych dwudziestu latach XXI w. Przekształcenia były efektem braku konsekwencji we wdrażaniu przyjętych rozwiązań oraz niecierpliwości rządzących, co skutkowało gruntownymi zmianami podejścia do mieszkalnictwa praktycznie przy każdym przetasowaniu na scenie politycznej. Do momentu wdrożenia Narodowego Programu Mieszkaniowego (NPM) dla polityki mieszkaniowej była właściwa fragmentaryczność rozwiązań - brakowało kompleksowego podejścia do problemu rozwoju mieszkalnictwa w Polsce. Cztery lata wdrażania i realizacji NPM to dobry moment, aby dokonać pierwszych podsumowań efektów oraz zastanowić się nad wprowadzeniem zmian do programu, które mogą zwiększyć jego skuteczność w kolejnej dekadzie.

Celem artykułu jest zweryfikowanie efektywności Narodowego Programu Mieszkaniowego, szczególnie jego społecznej części związanej z pakietem Mieszkanie Plus. Wnioski z przeprowadzonych analiz mają posłużyć do sformułowania rekomendacji co do dalszego funkcjonowania 
programu. W opracowaniu Narodowy Program Mieszkaniowy zostanie opisany w kontekście teoretycznych założeń społecznej polityki mieszkaniowej oraz jej realizacji w Polsce w pierwszym dwudziestoleciu XXI w. Na podstawie danych z raportów rządowych oraz innych źródeł zostaną wyciągnięte i przedstawione wnioski na temat skuteczności NPM.

\section{Społeczna polityka mieszkaniowa - ramy teoretyczne}

„Dach nad głową" to jedna z podstawowych potrzeb egzystencjalnych każdego człowieka. Jednocześnie standard mieszkalnictwa jest przejawem dobrobytu danego społeczeństwa. Niski poziom zaspokojenia potrzeb mieszkaniowych ma wiele negatywnych konsekwencji zarówno dla rynku pracy, jak i demografii, a nawet stabilności politycznej i społecznej'. Upowszechnianie się koncepcji państwa opiekuńczego (welfare state) spowodowało, że prawo do mieszkania traktowane jest jako podstawowe prawo obywatelskie w krajach wysoko rozwiniętych, a odpowiedzialność za zapewnienie godziwych warunków mieszkaniowych została przesunięta z obywatela lub rodziny na władze publiczne ${ }^{2}$. Nic zatem dziwnego, że również w Polsce zapewnienie prawa do mieszkania, jako swoistego prawa człowieka czy prawa obywatelskiego, było tak ważnym zagadnieniem, że zostało uwzględnione w najważniejszej ustawie - Konstytucji $\mathrm{RP}^{3}$ : „Władze publiczne prowadzą politykę sprzyjającą zaspokojeniu potrzeb mieszkaniowych obywateli, w szczególności przeciwdziałają bezdomności, wspierają rozwój budownictwa socjalnego oraz popierają działania obywateli zmierzające do uzyskania własnego mieszkania ${ }^{4 \prime}$.

Politykę mieszkaniową klasyfikuje się jako jedną z polityk ekonomicznych, która polega na regulowaniu działania rynku mieszkaniowego, tak aby pozwalał na efektywną produkcję budowlano-montażową, oraz na usuwaniu jego ewentualnych niedoskonałości. Kwestią sporną pozostaje zakres ingerencji państwa w mechanizmy wolnorynkowe przez dobór kryteriów sprawiedliwego podziału majątku trwałego między ludzi. Niekomercyjny rynek mieszkaniowy, skierowany do osób w trudnej sytuacji materialnej, nie powinien zaburzać funkcjonowania rynku komercyjnego (deweloperskiego), na którym mieszkania wciąż są dobrem pożądanym. Podstawą formułowania szczegółowych zadań polityki mieszkaniowej powinna być diagnoza potrzeb mieszkaniowych i popytu na mieszkania. Cele polityki mieszkaniowej można podzielić na dwie główne kategorie, czyli dotyczące strony popytowej (w zakresie warunków do nabycia lub najmu mieszkań przez wszystkich obywateli) oraz strony podażowej (kwestia dostępności i utrzymania odpowiedniej jakości zasobu mieszkaniowego) ${ }^{5}$.

1 E. Polak, Rozwój zintegrowany a dobrobyt społeczno-ekonomiczny - kłopoty z pomiarem, „Nierówności Spoteczne a Wzrost Gospodarczy" 2014, nr 1(37), s. 8-9.

2 M. Lux, Public Housing Policies: Economic and Social Perspectives [w:] Housing Policy: An End Or a New Beginning?, red. M. Lux, Open Society Institute, Budapest 2003, s. 9.

3 M. Bernaczyk, Konstytucyjne obowiq̨zki państwa do podejmowania działań w zakresie zaspokajania potrzeb mieszkaniowych jednostki [w:] Realizacja i ochrona konstytucyjnych wolności i praw jednostki w polskim porządku prawnym, red. M. Jabłoński, Uniwersytet Wrocławski, Wrocław 2014, s. 755.

4 Konstytucja Rzeczypospolitej Polskiej z dnia 2 kwietnia 1997 r. (Dz.U. nr 78, poz. 483, ze zm.), art. 75.

5 P. Lis, Cele i instrumenty społecznej polityki mieszkaniowej, „Space - Society - Economy” 2011, nr 10, s. 10-11. 
W myśl podstawowego założenia głównym celem polityki mieszkaniowej jest wsparcie gospodarstw domowych w zaspokajaniu ich potrzeb mieszkaniowych zgodnie z indywidualnymi preferencjami, aspiracjami, jak również możliwościami ekonomicznymi. Można tego dokonać dzięki zastosowaniu odpowiednich narzędzi na etapie procesu inwestycyjnego, w fazie nabywania prawa do mieszkania, a nawet $w$ fazie eksploatacji zasobu mieszkaniowego ${ }^{6}$. Wśród celów szczegółowych polityki mieszkaniowej można wyróżnić:

- zwiększenie efektów rzeczowych budownictwa mieszkaniowego, w tym rozwój budownictwa na wynajem,

- zapewnienie schronienia najuboższym,

- poprawę stanu technicznego zasobu mieszkaniowego ${ }^{7}$.

W tym kontekście społeczna polityka mieszkaniowa stanowi osobną kategorię. Polega na redystrybucji dochodów „w celu wspomagania wzrostu konsumpcji usług mieszkaniowych przez ludność niezamożną"8. W skrajnym przypadku, a zatem w odniesieniu do najuboższych, polega ona na zapewnianiu im mieszkań, najczęściej o niższym standardzie, z symbolicznymi czynszami lub wręcz nieodpłatnie. Takie podejście do polityki mieszkaniowej jest uzasadnione, ponieważ uboższa część społeczeństwa, ze względu na specyfikę rynku nieruchomości związaną z wysoką kapitałochłonnością, nie ma możliwości zapewnienia sobie „dachu nad głową" samodzielnie. Wówczas rolą państwa jest zagwarantowanie wszystkim obywatelom godnych, co nie znaczy - luksusowych, warunków zamieszkania99. Społeczna polityka mieszkaniowa jest również nieodzownym elementem polityki społecznej w krajach o chłodniejszym klimacie, w których brak dostępu do mieszkań może powodować wręcz zagrożenie dla życia ludzi.

Społeczna polityka mieszkaniowa jest skierowana głównie do osób zagrożonych wykluczeniem społecznym, gdyż brak dostępności odpowiednich zasobów mieszkaniowych oraz jego radykalna forma w postaci bezdomności to istotne przyczyny ekskluzji społecznej. Czynników wykluczających związanych z miejscem zamieszkania jest jednak zdecydowanie więcej, na przykład może nim być złe sąsiedztwo, które negatywnie wpływa na swobodę wypoczynku czy życie rodzinne $^{10}$. Do celów społecznej polityki mieszkaniowej należą zatem:

- określenie zasad alokacji społecznego zasobu mieszkaniowego i dostępu do niego,

- oszacowanie zdolności gospodarstw domowych do nabycia/wynajmu mieszkań w budownictwie społecznym,

- ustalenie zakresu ochrony prawnej lokatorów i właścicieli społecznego zasobu mieszkaniowego ${ }^{11}$.

6 B. Krystek-Kucewicz et al., Zintegrowana polityka mieszkaniowa polskich gmin, Instytut Rozwoju Miast i Regionów, Warszawa 2020, s. 7-11.

7 R. Cyran, Zintegrowana polityka mieszkaniowa jako instrument rozwoju lokalnego , „Studia Ekonomiczne” 2013, nr 144, cz. 2, s. 217.

8 M. Cesarski, Społeczna polityka mieszkaniowa w poszukiwaniu i urzeczywistnianiu trwałego rozwoju, „Kwartalnik Kolegium Ekonomiczno-Społecznego. Studia i Prace" 2017, nr 3, s. 12-13, https://doi.org/10.33119/ kkessip.2017.3.1.

9 M. Bryx, O prawie do dachu nad głowq , "Problemy Rozwoju Miast” 2007, nr 4, s. 7.

10 M. Sobczak, Wykluczenie społeczne i inkluzja społeczna z wykorzystaniem podmiotów ekonomii społecznej w Polsce na przykładzie województwa tódzkiego, Wydawnictwo Uniwersytetu Łódzkiego, Łódź 2016, s. 21.

11 P. Lis, Cele i instrumenty..., s. 12. 
Cele oraz zadania polityki mieszkaniowej realizuje się za pomocą wielu instrumentów, takich jak: regulacje rynku mieszkaniowego, transfery na rzecz uczestników tego rynku, inwestycje w społeczny zasób mieszkaniowy, podatki związane z wynajmem oraz własnością zasobu mieszkaniowego. Wśród instrumentów polityki mieszkaniowej wyróżnia się bezpośrednie i pośrednie, co zaprezentowano w tabeli $1^{12}$.

\section{Tabela 1. Instrumenty polityki mieszkaniowej}

\begin{tabular}{|l|l|}
\multicolumn{1}{|c|}{ Instrumenty bezpośrednie } & \multicolumn{1}{c|}{ Instrumenty pośrednie } \\
\hline budownictwo społeczne & regulacje rynku \\
\hline subsydia w społecznym zasobie mieszkaniowym & instytucjonalne wsparcie państwa \\
\hline & subsydia finansowe (np. dopłaty do kredytów) \\
\hline
\end{tabular}

Źródło: opracowanie własne na podstawie: P. Lis, Polityka mieszkaniowa dla Polski. Dlaczego potrzeba więcej mieszkań na wynajem i czy powinno je budować państwo?, Forum Idei, Fundacja im. Stefana Batorego, Warszawa 2019, s. 6.

Skuteczną politykę mieszkaniową charakteryzuje posługiwanie się odpowiednią kombinacją wszystkich wyżej wymienionych instrumentów. Kwestią wyboru pozostaje to, które narzędzia wykorzystywać w większym stopniu, co wynika zazwyczaj z postawionych celów oraz sytuacji gospodarczej w kraju. W Polsce od czasów przemian ustrojowych na poziomie centralnym i lokalnym stosowano szeroki wachlarz instrumentów służących wsparciu rozwoju mieszkalnictwa, na który składały się:

- programy nakierowane na wsparcie młodych,

- dostęp do publicznych mieszkań na wynajem (komunalnych, TBS-ów itp.),

- wsparcie dla budownictwa mieszkań socjalnych,

- wsparcie oszczędzania na cele mieszkaniowe,

- wypłata premii dla posiadaczy książeczek mieszkaniowych w momencie kupna mieszkania lub budowy domu,

- wsparcie modernizacji i napraw istniejących zasobów mieszkaniowych,

- odpowiednie planowanie przestrzenne,

- uzbrajanie terenów,

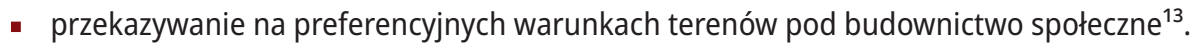

Mimo bogatego instrumentarium trudno nazwać polską politykę mieszkaniową skuteczną, o czym świadczą dane o trwającym od lat deficycie mieszkań, który można oszacować na ok. 641 tys. Jednocześnie w 2019 r. 1,9 mln osób (4,5\% gospodarstw domowych) zamieszkiwało wspólnie z innym gospodarstwem domowym ${ }^{14}$. Polityka mieszkaniowa w Polsce charakteryzowała się bowiem zbyt częstymi zmianami podejścia do problemu oraz brakiem całościowej strategii działania.

12 P. Lis, Polityka mieszkaniowa dla Polski. Dlaczego potrzeba więcej mieszkań na wynajem i czy powinno je budować państwo?, Forum Idei, Fundacja im. Stefana Batorego, Warszawa 2019, s. 6.

13 I. Rącka, A. Bieda, Local Instruments of Housing Policy in Poland, "Świat Nieruchomości” 2017, nr 102, s. 40-41.

14 Ministerstwo Rozwoju, Sprawozdanie z realizacji działań w ramach Narodowego Programu Mieszkaniowego w 2019 roku, Warszawa 2020, s. 8. 


\section{Programy polityki mieszkaniowej w Polsce w XXI w.}

W XXI w. kwestia niedoboru mieszkań oraz ich wysokich cen w stosunku do dochodów ludności była ważnym tematem dyskursu publicznego. Niestety problemowi temu towarzyszyła wyjątkowa niestabilność polityki mieszkaniowej. Niezadowalające efekty kolejnych programów, najczęściej ocenianych z dość krótkiej perspektywy czasowej, skutkowały tym, że praktycznie każda nowa władza w Polsce wdrażała własne programy mieszkaniowe, a z poprzednich się wycofywała ${ }^{15}$. Przy czym warto podkreślić, że jednym z powodów nieskuteczności polityki mieszkaniowej mogła być właśnie dość duża zmienność realizowanych rozwiązań. Oto lista najważniejszych działań z zakresu polityki mieszkaniowej w Polsce w XXI w.:

- ulgi podatkowe i inne instrumenty fiskalne,

- Krajowy Fundusz Mieszkaniowy (1996-2009),

- program wsparcia budownictwa socjalnego i komunalnego (od 2007),

- Rodzina na Swoim (2007-2013),

- Mieszkanie dla Młodych (2014-2018),

- Narodowy Program Mieszkaniowy (od 2016) wraz z pakietem Mieszkanie Plus.

Pierwsze narzędzie polityki mieszkaniowej stosowane w Polsce to ulgi podatkowe, które określa się jako przewidziane w prawie podatkowym zwolnienia, odliczenia, obniżki albo zmniejszenia, skutkujące obniżeniem podstawy opodatkowania lub wysokości podatku. Takie instrumenty przyczyniają się do podejmowania przez podatników pożądanych przez ustawodawcę decyzji. Dzięki temu mechanizmowi oczekuje się osiągnięcia ważnych, z punktu widzenia gospodarki czy społeczeństwa, efektów ${ }^{16}$, takich jak: wzrost liczby inwestycji mieszkaniowych, poprawa warunków technicznych nieruchomości mieszkalnych czy zastosowanie technologii proekologicznych w mieszkalnictwie. W Polsce od początku XXI w. funkcjonowało wiele różnych ulg podatkowych, które były związane z szeroko rozumianą polityką mieszkaniową ${ }^{17}$. Paradoksalnie czasem zbyt duża popularność niektórych z nich wśród podatników skutkowała tym, że rządzący je wycofywali. Przez kolejne lata instrument ten coraz rzadziej wykorzystywano w polityce mieszkaniowej w Polsce, a od 2010 r. jego znaczenie było marginalne. Różnorodność ulg podatkowych związanych z mieszkalnictwem była jednak w Polsce w latach 2000-2020 bardzo duża, a wśród preferencji znalazły się:

- ulga z tytułu oszczędzania w kasie mieszkaniowej (do 2001),

- ulga budowlana (do 2001),

- ulga za wynajem (do 2001),

- ulga remontowa, umożliwiająca odliczenie kosztów remontu (2002-2005),

- ulga odsetkowa, czyli możliwość odliczenia odsetek od kredytów mieszkaniowych (2002-2006),

15 R. Szarfenberg, Polska polityka mieszkaniowa na zakręcie? [w:] Polityka mieszkaniowa, red. M. Polakowski, R. Szarfenberg, A. Zubrzycka-Czarnecka, K. Święcicka, Friedrich-Ebert-Stiftung, Warszawa 2017, s. 7-8.

16 W. Wyrzykowski, P. Kasprzak, Ulga podatkowa jako instrument realizacji pozafiskalnych funkcji podatków, „Zarządzanie Finansami i Rachunkowość" 2016, t. 4, nr 1, s. 19-20.

17 K. Święch, Pozycja rodziny w polskim prawie podatkowym, Wolters Kluwer Polska, Warszawa 2013, s. $192-207$. 
- ulga meldunkowa, pozwalająca nie płacić podatku od sprzedaży nieruchomości pod warunkiem, że sprzedawca był w tym mieszkaniu zameldowany przynajmniej przez rok (2008),

- ulga mieszkaniowa dla podatników, którzy sprzedali nieruchomość najpóźniej po pięciu latach od jej nabycia, a dochód ze sprzedaży przeznaczyli na cele mieszkaniowe (od 2009) ${ }^{18}$,

- ulga termomodernizacyjna, czyli odliczenie od dochodów wydatków na termomodernizację budynków jednorodzinnych (od 2019) ${ }^{19}$.

Bardzo istotną instytucją w Polsce z punktu widzenia wdrażania kolejnych programów z zakresu społecznej polityki mieszkaniowej był Bank Gospodarstwa Krajowego (BGK), który koordynował każdy z nich. Pierwszy program to funkcjonujący w latach 1996-2009 Krajowy Fundusz Mieszkaniowy ${ }^{20}$, z którego udzielono ponad 1,8 tys. preferencyjnie oprocentowanych kredytów. Dzięki temu oddano do użytku ok. 81 tys. mieszkań wybudowanych przez towarzystwa budownictwa społecznego (TBS) oraz przeszło 17 tys. - przez spółdzielnie mieszkaniowe, najczęściej z przeznaczeniem na użytkowanie w formule lokatorskiego spółdzielczego prawa do lokalu ${ }^{21}$.

W 2007 r. BGK uruchomił program wsparcia budownictwa socjalnego i komunalnego ${ }^{22}$, który oparto na funduszu dopłat skierowanym do gmin, powiatów, związków międzygminnych i organizacji pożytku publicznego. W jego ramach oferuje się bezzwrotne dotacje w wysokości maks. $60 \%$ kosztów inwestycji związanej z utworzeniem lokali socjalnych, mieszkań chronionych, noclegowni i domów dla bezdomnych. Celem tego programu było zwiększenie podaży tego typu lokali, choć można z niego finansować bezpośrednio również inne inwestycje (np. w mieszkania komunalne), pod warunkiem przekształcenia takiej samej liczby lokali ze „starego" zasobu komunalnego na cele wymienione w ustawie ${ }^{23}$. Do lutego 2019 r. ze środków funduszu sfinansowano wybudowanie 19 tys. mieszkań (6,7 tys. było w trakcie realizacji) oraz 1,1 tys. miejsc noclegowych dla bezdomnych ${ }^{24}$.

Inną konstrukcję zastosowano w przypadku dwóch kolejnych programów, które nie były związane z bezpośrednim dofinansowywaniem inwestycji, czyli funkcjonującego w latach 20072013 programu Rodzina na Swoim ${ }^{25}$ oraz programu Mieszkanie dla Młodych (MdM), do którego

18 https://businessinsider.com.pl/twoje-pieniadze/prawo-i-podatki/historia-podatku-pit-w-polsce-jak-sie-zmienialy-ulgi-i-stawki/cmkpcbt [dostęp: 7 lipca 2021 r.].

19 https://www.podatki.gov.pl/pit/ulgi-odliczenia-i-zwolnienia/ulga-termomodernizacyjna/ [dostęp: 7 lipca 2021 r.].

20 Ustawa z dnia 26 października 1995 r. o niektórych formach popierania budownictwa mieszkaniowego (Dz.U. 2019, poz. 2195, ze zm.).

21 https://www.bgk.pl/przedsiebiorstwa/fundusze-i-programy/program-wspierania-spolecznego-budownictwa-czynszowego/ [dostęp: 7 lipca 2020 r.].

22 Ustawa z dnia 8 grudnia 2006 r. o finansowym wsparciu tworzenia lokali mieszkalnych na wynajem, mieszkań chronionych, noclegowni, schronisk dla bezdomnych, ogrzewalni i tymczasowych pomieszczeń (Dz.U. 2020, poz. 1844, ze zm.).

23 Ibidem, art. 21 pkt 10.

24 https://www.bgk.pl/aktualnosci/miliard-rocznie-dla-gmin-bgk-wspiera-budownictwo-komunalne-i-socjalne-2525/ [dostęp: 7 lipca 2021 r.].

25 Ustawa z dnia 8 września 2006 r. o finansowym wsparciu rodzin i innych osób w nabywaniu własnego mieszkania (Dz.U. 2021, poz. 403). 
można było przystąpić w latach 2014-2018 ${ }^{26}$. W ramach pierwszego oferowano małżeństwom, osobom samotnie wychowującym dzieci oraz - od 2011 r. - osobom w związkach nieformalnych kredyt preferencyjny, czyli z dopłatami do oprocentowania, który było można przeznaczyć na zakup lub budowę lokalu mieszkalnego albo domu na rynku pierwotnym lub remont domu bądź mieszkania na rynku wtórnym. Osobom ubiegającym się o kredyt preferencyjny nie mógł przysługiwać żaden tytuł prawny do lokalu mieszkalnego, a z programu można było skorzystać tylko raz w życiu ${ }^{27}$. W ramach programu Rodzina na Swoim udzielono ponad 192 tys. kredytów ${ }^{28}$. Jego kontynuacją był MdM, z tym że dopłaty do odsetek zastąpiono dopłatami do wkładu własnego, co miało pomóc młodym ludziom w zakupie pierwszego mieszkania lub domu jednorodzinnego. Wysokość dofinansowania była uzależniona od liczby wychowywanych przez beneficjentów dzieci. Jednocześnie program był skierowany do osób poniżej 35. roku życia, a w przypadku mieszkań i domów przewidziano limity cenowe oraz powierzchniowe. W ramach programu Mieszkanie dla Młodych na dopłaty rozdysponowano prawie $3 \mathrm{mld}$ zł, a liczba beneficjentów przekroczyła 110 tys. $^{29}$

\section{Założenia Narodowego Programu Mieszkaniowego}

Od początku XXI w. polska polityka mieszkaniowa charakteryzowała się fragmentarycznością rozwiązań i doraźnością działań. Wielokrotnie, często w odstępach kilku lat, była znacząco zmieniana, a więc brakowało konsekwencji w działaniu oraz jasno określonej wieloletniej koncepcji czy głównych długookresowych celów ${ }^{30}$. Z tej perspektywy, przynajmniej w założeniach, Narodowy Program Mieszkaniowy ${ }^{31}$ wydaje się zmianą w dobrym kierunku. Wdrożeniu NPM towarzyszy zmiana modelu polityki mieszkaniowej w Polsce. Wprowadzane nowe programy adresowane są w zasadzie już tylko do niezamożnych gospodarstw domowych, w przypadku których dostęp do nowo tworzonych mieszkań będzie miał charakter nierynkowy ${ }^{32}$. Dopiero za kilka lat będzie jednak możliwa pełna ocena NPM po odpowiedniej ewaluacji jego wdrażania, trwałości i po przeglądzie osiągniętych efektów czy zrealizowanych celów.

Podstawą do opracowania programu była szczegółowa diagnoza sytuacji mieszkaniowej w Polsce, która wykazała przede wszystkim znaczące niedobory mieszkań na wynajem dla osób

26 Ustawa z dnia 27 września 2013 r. o pomocy państwa w nabyciu pierwszego mieszkania przez młodych ludzi (Dz.U. 2019, poz. 1116).

27 M. Majorek, Rzqdowy program „Rodzina na swoim”. Społeczne, ekonomiczne i medialne reperkusje wdrażania, „Państwo i Społeczeństwo" 2013, nr 3(13), s. 27-28.

28 Bank Gospodarstwa Krajowego, Dane liczbowe programu Rodzina na Swoim, Warszawa 2014.

29 M. Lewicki, Społeczne życie hipoteki, Wydawnictwo Naukowe Scholar, Warszawa 2019, s. 191.

30 M. Kędzierska, Kształtowanie polityki mieszkaniowej w warunkach gospodarki rynkowej, „Equilibrium” 2009, nr 1(2), s. 150.

31 Uchwała nr 115/2016 Rady Ministrów z dnia 27 września 2016 r. w sprawie przyjęcia Narodowego Programu Mieszkaniowego (RM-111-119-16), https://narodowyprogram.pl/wp-content/uploads/2017/03/ uchwa\%C5\%82a_narodowy_program_mieszkaniowy.pdf (dalej: Narodowy Program Mieszkaniowy).

32 A. Przymeński, Najem mieszkań na warunkach socjalnych w kontekście zmian modelu polityki mieszkaniowej w Polsce, „Polityka Społeczna” 2019, nr 9, s. 6. 
nieposiadających zdolności kredytowej. Dla rozwoju segmentu mieszkań socjalnych było zaś niezbędne uelastycznienie przepisów dotyczących najmu oraz wdrożenie odpowiednich rozwiązań skierowanych do inwestorów, a mających poprawić konkurencyjność takich inwestycji względem przedsięwzięć czysto komercyjnych ${ }^{33}$. Dzięki szczegółowej diagnozie było możliwe ułożenie odpowiedniego planu działań. NPM zakłada osiągnięcie trzech podstawowych celów, którym przyporządkowano odpowiednie działania (tabela 2).

\section{Tabela 2. Główne cele i działania Narodowego Programu Mieszkaniowego}

\begin{tabular}{|c|c|}
\hline Cele & Działania \\
\hline $\begin{array}{l}\text { Cel 1. Zwiększenie } \\
\text { dostępu do mieszkań } \\
\text { dla osób o dochodach } \\
\text { uniemożliwiających } \\
\text { nabycie lub wynajęcie } \\
\text { mieszkania na zasadach } \\
\text { komercyjnych }\end{array}$ & $\begin{array}{l}\text { - zwiększenie podaży mieszkań o niskim czynszu oraz aktywizacja podmiotów } \\
\text { dostarczających tego typu mieszkania } \\
\text { - obniżenie kosztów budowy mieszkań, w szczególności przez tworzenie } \\
\text { warunków regulacyjnych, wykorzystanie podaży dostępnych gruntów } \\
\text { publicznych pod budownictwo mieszkaniowe oraz upowszechnianie } \\
\text { optymalnych technologii i projektów architektonicznych w zakresie szeroko } \\
\text { rozumianego społecznego budownictwa } \\
\text { - zachęcanie do systematycznego oszczędzania na cele mieszkaniowe } \\
\text { - ułatwienie podmiotom instytucjonalnym inwestowania na rynku mieszkań } \\
\text { na wynajem }\end{array}$ \\
\hline $\begin{array}{l}\text { Cel 2. Zwiększenie } \\
\text { możliwości zaspokojenia } \\
\text { podstawowych potrzeb } \\
\text { mieszkaniowych } \\
\text { osób zagrożonych } \\
\text { wykluczeniem społecznym } \\
\text { ze względu na niskie } \\
\text { dochody lub szczególnie } \\
\text { trudną sytuację życiową }\end{array}$ & $\begin{array}{l}\text { - zwiększenie możliwości gmin w zakresie dostarczania lokali socjalnych / } \\
\text { mieszkań komunalnych } \\
\text { - rozwój mieszkalnictwa wspomaganego (np. chronionego) } \\
\text { - redukcja skutków bezdomności przez zapewnienie odpowiedniej liczby miejsc } \\
\text { w noclegowniach i schroniskach dla bezdomnych } \\
\text { - wypracowanie i wdrożenie strategicznego podejścia w ramach polityki } \\
\text { mieszkaniowej do potrzeb mieszkaniowych grup o specjalnych potrzebach } \\
\text { mieszkaniowych, w szczególności osób starszych i niepełnosprawnych } \\
\text { - pomoc osobom znajdującym się w przejściowo trudnej sytuacji finansowej, } \\
\text { wpływającej m.in. na możliwość uiszczania opłat za mieszkanie lub spłat kredytu } \\
\text { hipotecznego }\end{array}$ \\
\hline $\begin{array}{l}\text { Cel 3. Poprawa warunków } \\
\text { mieszkaniowych } \\
\text { społeczeństwa, stanu } \\
\text { technicznego zasobów } \\
\text { mieszkaniowych oraz } \\
\text { zwiększenie efektywności } \\
\text { energetycznej }\end{array}$ & $\begin{array}{l}\text { - racjonalizacja zasad zarządzania budynkami i lokalami mieszkalnymi w zasobie } \\
\text { - wspieranym } \\
\text { inwestycji podejmowanych w ramach projektów rewitalizacji obszarów } \\
\text { zdegradowanych } \\
\text { - zapewnianie infrastruktury technicznej towarzyszącej budownictwu } \\
\text { mieszkaniowemu }\end{array}$ \\
\hline
\end{tabular}

Źródło: opracowanie własne na podstawie: Ministerstwo Infrastruktury i Budownictwa, Narodowy Program Mieszkaniowy, Warszawa 2016, s. 49-50.

Aby skutecznie zrealizować powyższe cele, niezbędne okazało się też podjęcie serii działań regulacyjnych oraz wdrożenie właściwych, towarzyszących im instrumentów finansowych. Działania te zostały podporządkowane czterem priorytetom, którym przypisano odpowiednie instrumenty:

33 L. Groeger, Programy wspierania budownictwa mieszkaniowego w Polsce i ich wpływ na rynek nieruchomości mieszkaniowych, "Space - Society - Economy” 2016, nr 18 [Uwarunkowania polityki mieszkaniowej w Polsce i na Ukrainie, red. E. Masierek], s. 145, https://doi.org/10.18778/1733-3180.18.09. 
1. Dostępne mieszkania (tzw. pakiet Mieszkanie Plus):

- kreowanie podaży dostępnych mieszkań na wynajem, w tym z opcją dochodzenia do własności (realizowane przez Krajowy Zasób Nieruchomości oraz PFR Nieruchomości),

- $\quad$ wsparcie społecznego budownictwa czynszowego (realizowane m.in. przez spółdzielnie mieszkaniowe oraz towarzystwa budownictwa społecznego),

- systematyczne oszczędzanie.

2. Stabilne i efektywne finansowanie:

- Narodowy Fundusz Mieszkaniowy,

- finansowanie wieloletnie,

- racjonalizacja zasad wydatkowania środków.

3. Nowoczesne, efektywne energetycznie i bezpieczne technicznie mieszkania:

- remonty,

- termomodernizacje,

- poprawa stanu technicznego zasobów w ramach rewitalizacji.

4. Dobre prawo:

- prawo mieszkaniowe,

- regulacje dotyczące procesu inwestycyjnego,

- regulacje dotyczące rynku finansowego ${ }^{34}$.

Zanim na dobre rozpoczęto wdrażanie NPM, pojawiły się w programie pierwsze zmiany, co nie najlepiej świadczy o jakości konsultacji społecznych przeprowadzonych podczas jego opracowywania. Zmiany dotyczyły najbardziej popularnego pakietu Mieszkanie Plus, w którym po rekomendacji Rady Mieszkalnictwa zrezygnowano z instrumentu systematycznego oszczędzania, jakim miały być indywidualne konta mieszkaniowe. Zaproponowano w zamian uruchomienie programu dopłat do czynszu w zasobach na wynajem Mieszkanie na Start ${ }^{35}$. Wynikało to z chęci szybszego i efektywniejszego rozstrzygnięcia problemu mieszkalnictwa w Polsce, jakim był zbyt niski dochód niepozwalający zaspokoić potrzeb mieszkaniowych rodzin. Dopłaty do czynszu są w tym przypadku dobrym rozwiązaniem, natomiast programy oszczędzania to inicjatywy długoterminowe, przez co ich efekty byłyby zbyt odsunięte w czasie w stosunku do oczekiwań i potrzeb ${ }^{36}$. Głównym celem pakietu Mieszkanie Plus pozostała jednak budowa tanich mieszkań na wynajem dla osób ze zdolnością czynszową, choć niekoniecznie kredytową. Czynsze powinny być oparte na zasadach rynkowych (co ma pozwolić na uzyskanie w oczekiwanym czasie zwrotu z inwestycji), ale mogą być nieco niższe od stawek obowiązujących w danym momencie na rynku (w praktyce mieszkania z programu mają ceny najmu niższe o ok. 20-30\% od stawek rynkowych ${ }^{37}$ ). Wynaj-

34 Uchwała nr 115/2016..., s. 51-54.

35 Ministerstwo Inwestycji i Rozwoju, Sprawozdanie z realizacji działań w ramach Narodowego Programu Mieszkaniowego w 2018 roku, Warszawa 2019, s. 35.

36 J. Żylińska, Mieszkanie Plus: Co dalej z indywidualnymi kontami mieszkaniowymi?, "Dziennik Gazeta Prawna”, https://serwisy.gazetaprawna.pl/nieruchomosci/artykuly/1417962,los-indywidualnych-kont-w-mieszkaniu-przypieczetowany.html [dostęp: 7 lipca 2021 r.].

37 M. Hojniak, Czy Mieszkanie Plus się opłaca? Porównujemy ceny, Krajowy Rynek Nieruchomości, https://www. krn.pl/artykul/czy-mieszkanie-plus-sie-oplaca-porownujemy-ceny,3147 [dostęp: 7 lipca 2021 r.]. 
mujący mogą wybrać opcję czynszu z dojściem do własności lokalu ${ }^{38}$. W ramach programu na dzień 30 marca 2020 r. wybudowano jednak tylko 867 mieszkań, a 1907 było w budowie. Kolejne przeszło 40 tys. było w fazie projektowania bądź analiz ${ }^{39}$.

Oprócz mieszkań na wynajem pakiet Mieszkanie Plus objął również społeczne budownictwo czynszowe. Dostęp do takich lokali mieszkalnych powinien odbywać się na zasadach nierynkowych, zgodnie z kryteriami określonymi przez władze publiczne. Działania inwestycyjne mogą podejmować tylko podmioty, które nie są nastawione na maksymalizację zysku, takie jak TBS-y, spółdzielnie mieszkaniowe czy spółki komunalne ${ }^{40}$. Bank Gospodarstwa Krajowego, który jest koordynatorem programu, oferuje podmiotom realizującym inwestycje wsparcie ze środków publicznych na następujących zasadach:

- kredyt lub organizacja emisji obligacji (z gwarancją ich nabycia),

- oprocentowanie zmienne, równe stopie WIBOR 3M, bez marży banku,

- maksymalny udział w kosztach planowanego przedsięwzięcia inwestycyjno-budowlanego $80 \%$,

- maksymalny okres finansowania - 30 lat.

Roczna alokacja środków w tym programie została ustalona na 450 mln zł, a do dnia 30 marca 2020 r. wybudowano w jego ramach ok. 2,5 tys. mieszkańn ${ }^{41}$, co również wydaje się niesatysfakcjonujące. Przyczyny tego stanu rzeczy powinny być przedmiotem dalszych analiz osób odpowiedzialnych za monitoring efektów NPM. Częściowo zagadnienie to zostanie opisane w dalszej części artykułu.

\section{Efekty Narodowego Programu Mieszkaniowego}

W Narodowym Programie Mieszkaniowym podano wiele wskaźników, których wartość docelowa koresponduje z celami całego programu. Corocznie dokonywana jest ewaluacja NPM, na podstawie której można ocenić postępy we wdrażaniu założeń strategii. Tabela 3 zawiera dane o efektach realizacji poszczególnych celów ilościowych.

Według powyższych danych najlepiej realizowany był cel 1 w zakresie liczby mieszkań na 1000 mieszkańców - w 2019 r. liczba mieszkań na 1000 mieszkańców wzrosła w porównaniu z 2014 r. o 22,2. Takie tempo przyrostu wskaźnika jest zadowalające i powinno pozwolić uzyskać zamierzony cel do 2030 r. Trzeba jednak pamiętać, że na osiągnięcie wspomnianego wyniku nie składają się efekty NPM, ale prawie wyłącznie komercyjnego budownictwa mieszkaniowego, które w okresach dobrej koniunktury bardzo szybko się rozwija. Otwarte pozostaje pytanie, jak na sektor komercyjny wpłyną epidemia koronawirusa i związany z nią kryzys ekonomiczny. Zdecydowanie poniżej oczekiwań przebiegała realizacja celu 2, związanego ze zmniejszeniem do zera liczby oczekujących na wynajem mieszkania z zasobów gminnych. Wskaźnik ten jest

38 https://kzn.bip.gov.pl/articles/pdf/107522 [dostęp: 7 lipca 2021 r.].

39 https://mplus.pl/ [dostęp: 30 marca 2020 r.].

40 Rada Mieszkalnictwa, Sprawozdanie z działalności w latach 2018-2019, Warszawa 2020, s. 26-27.

41 https://www.bgk.pl/przedsiebiorstwa/fundusze-i-programy/program-wspierania-spolecznego-budownictwa-czynszowego/ [dostęp: 30 marca 2020 r.]. 
Tabela 3. Wskaźniki celów Narodowego Programu Mieszkaniowego i postępy w ich realizacji

\begin{tabular}{|c|c|c|c|}
\hline Wskaźnik & $\begin{array}{l}\text { Wartość } \\
\text { wyjściowa }\end{array}$ & $\begin{array}{c}\text { Wartość } \\
\text { w poszczególnych } \\
\text { latach }\end{array}$ & $\begin{array}{l}\text { Wartość docelowa } \\
\text { (2030) }\end{array}$ \\
\hline \multicolumn{4}{|c|}{$\begin{array}{l}\text { Cel 1. Zwiększenie dostępu do mieszkań dla osób o dochodach uniemożliwiających obecnie nabycie lub } \\
\text { wynajęcie mieszkania na zasadach komercyjnych }\end{array}$} \\
\hline $\begin{array}{l}\text { Liczba mieszkań przypadająca na } \\
1000 \text { mieszkańców }\end{array}$ & 363,4 (2014) & $\begin{array}{ll}380,2 & (2018) \\
385,6 & (2019)\end{array}$ & 435 \\
\hline \multicolumn{4}{|c|}{$\begin{array}{l}\text { Cel 2. Zwiększenie możliwości zaspokojenia podstawowych potrzeb mieszkaniowych osób zagrożonych } \\
\text { wykluczeniem społecznym ze względu na niskie dochody lub szczególnie trudną sytuację życiową }\end{array}$} \\
\hline $\begin{array}{l}\text { Liczba gospodarstw domowych } \\
\text { oczekujących na wynajem mieszkania } \\
\text { gminnego }\end{array}$ & 165,2 tys. (2014) & $\begin{array}{l}154,2 \text { tys. }(2017) \\
149,3 \text { tys. }(2018) \\
150,6 \text { tys. }(2019)\end{array}$ & 0 \\
\hline \multicolumn{4}{|c|}{$\begin{array}{l}\text { Cel 3. Poprawa warunków mieszkaniowych społeczeństwa, stanu technicznego zasobów mieszkaniowych oraz } \\
\text { zwiększenie efektywności energetycznej }\end{array}$} \\
\hline $\begin{array}{l}\text { Liczba osób zamieszkujących w warunkach } \\
\text { substandardowych (przeludnienie, zły } \\
\text { stan techniczny lub brak odpowiednich } \\
\text { instalacji technicznych) }\end{array}$ & 5360,2 tys. (2011) & $\begin{array}{l}\text { brak danych } \\
\text { (dane z Narodowego } \\
\text { Spisu Powszechnego } \\
\text { Ludności i Mieszkań) }\end{array}$ & 3300,0 tys. \\
\hline
\end{tabular}

Źródło: opracowanie własne na podstawie: Ministerstwo Inwestycji i Rozwoju, Sprawozdanie z realizacji działań w ramach Narodowego Programu Mieszkaniowego w 2018 roku, Warszawa 2019, s. 8; Ministerstwo Rozwoju, Sprawozdanie z realizacji działań w ramach Narodowego Programu Mieszkaniowego w 2019 roku, Warszawa 2020, s. 7; Główny Urząd Statystyczny, Gospodarka mieszkaniowa w 2019 r., Warszawa 2020, s. 2.

mocno powiązany z pakietem Mieszkanie Plus, którego głównym celem jest właśnie wspieranie rozwoju tego typu budownictwa. Trudno jednak przypuszczać, że bez zdecydowanego przyspieszenia programu zbliżenie się do oczekiwanej wartości będzie możliwe, szczególnie że w 2019 r. wskaźnik ten wręcz pogorszył się w stosunku do roku poprzedniego. Realizacja celu 3, dotyczącego poprawy warunków mieszkaniowych społeczeństwa, aktualnie w ogóle nie jest monitorowana, a najbliższe dane na ten temat będzie można uzyskać w 2022 r., gdy zostaną upublicznione efekty Narodowego Spisu Powszechnego Ludności i Mieszkań z 2021 r.

Brakuje obecnie szczegółowych danych o stanie realizacji pakietu Mieszkanie Plus, gdyż dostępne wcześniej „liczniki” inwestycji zostały usunięte ze strony programu. Ostatnie szczegółowe informacje zdobyte przez autora pochodzą z 30 marca 2020 r. i zostały zaprezentowane w poprzednim podrozdziale. $Z$ informacji upublicznionych przez wiceminister rozwoju, pracy i technologii Annę Kornecką podczas posiedzenia sejmowej Komisji Infrastruktury oraz sejmowej Komisji Samorządu Terytorialnego i Polityki Regionalnej w dniu 19 stycznia 2021 r. na koniec 2020 r. liczba mieszkań wybudowanych i mieszkań w budowie w ramach pakietu Mieszkanie Plus wyniosła 26 182, w tym 3224 to mieszkania w ramach budownictwa na wynajem oraz 22958 - lokale przygotowywane na potrzeby społecznego budownictwa czynszowego ${ }^{42}$.

42 Kancelaria Sejmu Rzeczypospolitej Polskiej, Pełny zapis przebiegu posiedzenia Komisji Infrastruktury (nr 67), Komisji Samorzqdu Terytorialnego i Polityki Regionalnej (nr 50) z dnia 19 stycznia 2021 r., Warszawa 2021, s. 4-5, https://orka.sejm.gov.pl/zapisy9.nsf/0/38FA1A01DAECFF29C125866900528CA8/\%24File/0091009. pdf [dostęp: 7 lipca 2021 r.]. 
Efektów Narodowego Programu Mieszkaniowego nie można jednak mierzyć tylko wskaźnikami liczbowymi związanymi z budownictwem mieszkaniowym, gdyż w ramach programu było podejmowanych wiele działań, które miały na celu choćby poprawę ram organizacyjno-prawnych w zakresie polityki mieszkaniowej, a najważniejsze dotyczyły:

- prac legislacyjnych wpływających na sprawność procesów budowlanych i planowania przestrzennego,

- uelastycznienia zasad najmu mieszkań z zasobów komunalnych,

- powołania państwowej osoby prawnej, Krajowego Zasobu Nieruchomości (KZN), której powierzono zadania w zakresie gospodarowania nieruchomościami gruntowymi w celu wspierania budownictwa mieszkaniowego,

- uruchomienia instrumentów finansowych mających wspierać modernizację istniejącego zasobu, szczególnie w zakresie efektywności energetycznej i przyjazności dla środowiska.

Niestety do 2020 r. nie wprowadzono żadnych rozwiązań, które uprościłyby procesy inwestycyjne realizowane przez spółdzielnie mieszkaniowe i miały istotny wpływ na zachęcenie tego sektora do rozwoju działalności w zakresie budowania nowych zasobów mieszkaniowych ${ }^{43}$.

Warto zatem sprawdzić, jak wszelkie działania związane z NPM wpłynęły na budownictwo mieszkaniowe w Polsce ogółem. W tabeli 4 przedstawiono dane o liczbie mieszkań oddanych do użytkowania w wybranych latach XXI w.

\section{Tabela 4. Mieszkania oddane w latach 2000-2019 do użytku według formy organizacyjnej budownictwa}

\begin{tabular}{|l|r|r|r|r|r|r|r|}
\hline \multicolumn{1}{|c|}{ Forma budownictwa } & $\mathbf{2 0 0 0}$ & \multicolumn{2}{|c|}{$\mathbf{2 0 0 5}$} & $\mathbf{2 0 1 0}$ & \multicolumn{2}{|c|}{$\mathbf{2 0 1 5}$} & \multicolumn{2}{|c|}{$\mathbf{2 0 1 7}$} & \multicolumn{2}{|c|}{$\mathbf{2 0 1 8}$} & $\mathbf{2 0 1 9}$ \\
\hline spółdzielcze & 24391 & 8222 & 5052 & 2115 & 2311 & 3024 & 2167 \\
\hline zakładowe & 1205 & 543 & 290 & 467 & 146 & 129 & 292 \\
\hline komunalne & 1904 & 3563 & 3418 & 1686 & 1715 & 1863 & 1838 \\
\hline społeczne czynszowe & 4019 & 5412 & 3129 & 1265 & 1486 & 1510 & 2467 \\
\hline na sprzedaż lub wynajem & 20728 & 33047 & 53505 & 62420 & 105027 & 112317 & 131435 \\
\hline inwestycje indywidualne & 35542 & 63279 & 70441 & 79758 & 67657 & 66220 & 69226 \\
\hline ogółem & 87789 & 114066 & 135835 & 147711 & 178342 & 185063 & 207425 \\
\hline
\end{tabular}

Źródło: opracowanie własne na podstawie Banku Danych Lokalnych Głównego Urzędu Statystycznego (BDL GUS).

W Polsce w XXI w. można zauważyć wyraźną tendencję wzrostową w liczbie mieszkań oddawanych do użytku, co było związane głównie z przyrostem liczby oddawanych do użytku mieszkań na sprzedaż bądź wynajem komercyjny. Jednocześnie, czego można się było spodziewać po przeglądzie danych o pakiecie Mieszkanie Plus, nie widać specjalnego ożywienia w zakresie budownictwa spółdzielczego, komunalnego czy społecznego czynszowego. Co więcej, te formy budownictwa funkcjonowały zdecydowanie lepiej na początku XXI w., szczególnie w przypadku budownictwa spółdzielczego, w ramach którego oddawano wtedy do użytku więcej miesz-

43 Ministerstwo Rozwoju, op. cit., s. 18-70. 
kań niż z inwestycji deweloperskich. Mimo że liczba nowo wybudowanych mieszkań w Polsce zwiększyła się istotnie w porównaniu z początkiem wieku, to trzeba odnotować, że dalej była zdecydowanie niższa niż w rekordowym 1978 r., gdy oddano ponad 283 tys. mieszkań.

Dane zaprezentowane w tabeli 5 pokazują lekkie ożywienie w zakresie budownictwa mieszkaniowego w latach 2016-2019. Wcześniejsze rozważania prowadzą jednak do wniosku, że był to bardziej efekt silnego rozwoju budownictwa komercyjnego niż wdrażania NPM. Trudno jednak oczekiwać efektów tak dużego programu infrastrukturalnego po czterech latach jego trwania. Przeciętny czas budowy nowych budynków mieszkalnych wielorodzinnych w badanym okresie wręcz się wydłużył, a przy jego obliczeniu nie uwzględniono prac koncepcyjnych, planistycznych ani czasu potrzebnego na uzyskanie niezbędnych pozwoleń. Zmiany prawne, które w założeniach miały skrócić ten okres, zostały wdrożone dopiero w 2020 r.

Tabela 5. Wskaźniki względne mieszkalnictwa w Polsce w latach 2016-2019

\begin{tabular}{|c|c|c|c|c|}
\hline Wskaźniki & 2016 & 2017 & 2018 & 2019 \\
\hline mieszkania wybudowane na 1000 ludności & 4,3 & 4,6 & 4,8 & 5,4 \\
\hline mieszkania wybudowane na 1000 zawartych małżeństw & 844 & 926 & 962 & 1131 \\
\hline $\begin{array}{l}\text { powierzchnia użytkowa mieszkań oddanych do użytkowania na } \\
1000 \text { ludności w m² }\end{array}$ & 401,5 & 430,5 & 435,5 & 478,7 \\
\hline nowe budynki mieszkalne na 1000 ludności & 1,9 & 2,0 & 2,1 & 2,2 \\
\hline $\begin{array}{l}\text { przeciętny czas trwania budowy nowych budynków mieszkalnych } \\
\text { wielorodzinnych w miesiącach }\end{array}$ & 21,8 & 22,3 & 22,2 & 23,3 \\
\hline
\end{tabular}

Źródło: opracowanie własne na podstawie BDL GUS.

\section{Podsumowanie}

Narodowy Program Mieszkaniowy był pierwszą inicjatywą w XXI w. w Polsce, w której zastosowano całościowe podejście do polityki mieszkaniowej i porzucono praktykę krótkoterminowych, fragmentarycznych rozwiązań. Przewidziana perspektywa czasowa programu to 15 lat (do 2030 r.) i dopiero po upływie tego czasu powinna przyjść pora na jego pełną ewaluację. Oczywiście trzeba stale monitorować realizację NPM, a ewentualne niedociągnięcia na bieżąco korygować. Władze publiczne powinny jednak konsekwentnie wdrażać zaplanowane rozwiązania i nie odchodzić od realizacji tak złożonej polityki mieszkaniowej, zaplanowanej na wiele lat.

Gdy weźmie się pod uwagę cztery lata realizacji Narodowego Programu Mieszkaniowego, jego efekty materialne są dość skromne, a z pewnością - poniżej oczekiwań. Trudno też zakładać, że program ten będzie ewoluował w kolejnych latach, ponieważ kryzys w gospodarce spowodowany pandemią koronawirusa znacząco uszczuplił wpływy budżetowe samorządów, a tym samym ograniczył wydatki inwestycyjne. Trzeba też realnie ocenić, że oczekiwania polityków deklarujących wybudowanie 100 tys. mieszkań w krótkim czasie były zbyt wygórowane i od początku niemożliwe do spełnienia. Mieszkania oddane w NPM wybudowano dotychczas w ramach już trwających i zaawansowanych inwestycji i w momencie wdrażania programu zo- 
stały tylko pod niego „podpięte”. Zamknięcie całego procesu inwestycyjnego w ciągu trzech czy czterech lat, bez ekspertyz, zgód, projektów, lecz jedynie z wytypowanym gruntem pod budowę, jest praktycznie niewykonalne. Gdy zatem spojrzy się na sprawę obiektywnie, trudno oczekiwać w tak krótkim czasie zapowiadanych efektów, co nie oznacza, że program w dłuższej perspektywie ich nie przyniesie. Niepokoić może jednak to, że z ust przedstawicieli władz coraz częściej padają zapowiedzi wycofania się z NPM ${ }^{44}$, co tylko będzie powieleniem błędów popełnianych w polityce mieszkaniowej w Polsce w XXI w., a zatem potwierdzeniem krótkoterminowości rozwiązań i braku konsekwencji w działaniu, tak istotnej w wieloletniej działalności inwestycyjnej. Należy się jednak zastanowić, czy obecna sytuacja finansowa samorządów pozwoli im odgrywać przewidzianą dla nich rolę w procesie inwestycyjnym pakietu Mieszkanie Plus.

Sytuacja epidemiczna to jednak niejedyny problem związany z wdrażaniem NPM. Opieszałość w prowadzeniu wielu założonych w programie prac legislacyjnych można uznać za jedną z największych barier zmniejszających skuteczność NPM. Wiele niezbędnych rozstrzygnięć pojawiło się stosunkowo niedawno, lecz z powodu kryzysu epidemicznego nie przyniosły one jeszcze oczekiwanych rezultatów, wiele rozwiązań ciągle jest na etapie wczesnych prac legislacyjnych, co przekłada się na dość niską skuteczność programu w pierwszych latach jego funkcjonowania.

Po przeprowadzonej analizie zgromadzonego materiału można pokusić się o sformułowanie rekomendacji, które należy wziąć pod uwagę podczas dalszych prac nad efektywnym systemem mieszkalnictwa w Polsce. Brzmią one tak:

- Narodowy Program Mieszkaniowy należy reformować i usprawniać realizację jego założeń na podstawie ewaluacji poszczególnych jego komponentów. Ze względu na kompleksowy charakter NPM i wieloletnią perspektywę jego wdrożenia nie można od niego odchodzić, ale należy konsekwentnie wcielać go w życie.

- Należy przyspieszyć prace legislacyjne nad wieloma aspektami NPM, które mogą mieć kluczowe znaczenie dla usprawnienia procesów inwestycyjnych oraz zwiększenia uczestnictwa w programie samorządów czy partnerów społecznych, choćby sektora spółdzielczego.

- NPM wymaga więcej cierpliwości ze strony rządzących, gdyż wiele rozwiązań legislacyjnych wprowadzono niedawno, a należy pamiętać, że perspektywa nawet pięcioletnia dla działalności inwestycyjnej nie jest zbyt długa. Tym bardziej trudno oczekiwać efektów rozwiązań wprowadzonych w perspektywie roku czy dwóch lat, szczególnie w obliczu niepewnej sytuacji gospodarczej związanej z kryzysem epidemicznym.

\section{Bibliografia}

Bernaczyk M., Konstytucyjne obowiq̨zki państwa do podejmowania działań w zakresie zaspokajania potrzeb mieszkaniowych jednostki [w:] Realizacja i ochrona konstytucyjnych wolności i praw jednostki w polskim porządku prawnym, red. M. Jabłoński, Uniwersytet Wrocławski, Wrocław 2014.

44 https://innpoland.pl/165559,koniec-mieszkania-plus-gowin-bedzie-nowy-program-mieszkaniowy [dostęp: 7 lipca 2021 r.]. 
Bryx M., O prawie do dachu nad głowq, „Problemy Rozwoju Miast” 2007, nr 4.

Cesarski M., Społeczna polityka mieszkaniowa w poszukiwaniu i urzeczywistnianiu trwałego rozwoju, „Kwartalnik Kolegium Ekonomiczno-Społecznego. Studia i Prace" 2017, nr 3, https://doi.org/10.33119/kkessip.2017.3.1.

Cyran R., Zintegrowana polityka mieszkaniowa jako instrument rozwoju lokalnego, „Studia Ekonomiczne” 2013, nr 144, cz. 2 .

Groeger L., Programy wspierania budownictwa mieszkaniowego w Polsce i ich wpływ na rynek nieruchomości mieszkaniowych, "Space - Society - Economy” 2016, nr 18 [Uwarunkowania polityki mieszkaniowej w Polsce i na Ukrainie, red. E. Masierek], https://doi.org/10.18778/1733-3180.18.09.

Hojniak M., Czy Mieszkanie Plus się opłaca? Porównujemy ceny, https://www.krn.pl/artykul/czy-mieszkanie-plus-sie-oplaca-porownujemy-ceny,3147.

Kędzierska M., Kształtowanie polityki mieszkaniowej w warunkach gospodarki rynkowej, „Equilibrium” 2009, nr 1(2). Krystek-Kucewicz et al., Zintegrowana polityka mieszkaniowa polskich gmin, Instytut Rozwoju Miast i Regionów, Warszawa 2020.

Lewicki M., Społeczne życie hipoteki, Wydawnictwo Naukowe Scholar, Warszawa 2019.

Lis P., Cele i instrumenty społecznej polityki mieszkaniowej, "Space - Society - Economy” 2011, nr 10.

Lis P., Polityka mieszkaniowa dla Polski. Dlaczego potrzeba więcej mieszkań na wynajem i czy powinno je budować państwo?, Forum Idei, Fundacja im. Stefana Batorego, Warszawa 2019.

Lux M., Public Housing Policies: Economic and Social Perspectives [w:] Housing Policy: An End or A New Beginning?, red. M. Lux, Open Society Institute, Budapest 2003.

Majorek M., Rzqdowy program „Rodzina na swoim”. Społeczne, ekonomiczne i medialne reperkusje wdrażania, „Państwo i Społeczeństwo” 2013, nr 3(13).

Polak E., Rozwój zintegrowany a dobrobyt społeczno-ekonomiczny - kłopoty z pomiarem, „Nierówności Społeczne a Wzrost Gospodarczy" 2014, nr 1(37).

Przymeński A., Najem mieszkań na warunkach socjalnych w kontekście zmian modelu polityki mieszkaniowej w Polsce, „Polityka Społeczna" 2019, nr 9.

Rącka I., Bieda A., Local Instruments of Housing Policy in Poland, „Świat Nieruchomości” 2017, nr 102.

Sobczak M., Wykluczenie społeczne i inkluzja społeczna z wykorzystaniem podmiotów ekonomii społecznej w Polsce na przykładzie województwa łódzkiego, Wydawnictwo Uniwersytetu Łódzkiego, Łódź 2016.

Szarfenberg R., Polska polityka mieszkaniowa na zakręcie? [w:] Polityka mieszkaniowa, red. M. Polakowski, R. Szarfenberg, A. Zubrzycka-Czarnecka, K. Święcicka, Friedrich-Ebert-Stiftung, Warszawa 2017.

Święch K., Pozycja rodziny w polskim prawie podatkowym, Wolters Kluwer Polska, Warszawa 2013.

Wyrzykowski W., Kasprzak P., Ulga podatkowa jako instrument realizacji pozafiskalnych funkcji podatków, „Zarządzanie Finansami i Rachunkowość" 2016, t. 4, nr 1.

Żylińska J., Mieszkanie Plus: Co dalej z indywidualnymi kontami mieszkaniowymi?, „Dziennik Gazeta Prawna”, https://serwisy.gazetaprawna.pl/nieruchomosci/artykuly/1417962,los-indywidualnych-kont-w-mieszkaniu-przypieczetowany.html.

\section{Dokumenty}

Bank Gospodarstwa Krajowego, Dane liczbowe programu Rodzina na Swoim, Warszawa 2014.

Główny Urząd Statystyczny, Gospodarka mieszkaniowa w 2019 r., Warszawa 2020. 
Kancelaria Sejmu Rzeczypospolitej Polskiej, Pełny zapis przebiegu posiedzenia Komisji Infrastruktury (nr 67) i Komisji Samorzadu Terytorialnego i Polityki Regionalnej (nr 50) z dnia 19 stycznia 2021 r., Warszawa 2021, https://orka. sejm.gov.pl/zapisy9.nsf/0/38FA1A01DAECFF29C125866900528CA8/\%24File/0091009.pdf.

Ministerstwo Infrastruktury i Budownictwa, Narodowy Program Mieszkaniowy, Warszawa 2016.

Ministerstwo Inwestycji i Rozwoju, Sprawozdanie z realizacji działań w ramach Narodowego Programu Mieszkaniowego w 2018 roku, Warszawa 2019.

Ministerstwo Rozwoju, Sprawozdanie z realizacji działań w ramach Narodowego Programu Mieszkaniowego w 2019 roku, Warszawa 2020.

Rada Mieszkalnictwa, Sprawozdanie z działalności w latach 2018-2019, Warszawa 2020.

\section{Akty prawne}

Konstytucja Rzeczypospolitej Polskiej z dnia 2 kwietnia 1997 r. (Dz.U. nr 78, poz. 483, ze zm.).

Uchwała nr 115/2016 Rady Ministrów z dnia 27 września 2016 r. w sprawie przyjęcia Narodowego Programu Mieszkaniowego (RM-111-119-16), https://narodowyprogram.pl/wp-content/uploads/2017/03/uchwa\%C5\%82a_ narodowy_program_mieszkaniowy.pdf.

Ustawa z dnia 26 października 1995 r. o niektórych formach popierania budownictwa mieszkaniowego (Dz.U. 2019, poz. 2195, ze zm.).

Ustawa z dnia 8 września 2006 r. o finansowym wsparciu rodzin i innych osób w nabywaniu własnego mieszkania (Dz.U. 2021, poz. 403).

Ustawa z dnia 8 grudnia 2006 r. o finansowym wsparciu tworzenia lokali mieszkalnych na wynajem, mieszkań chronionych, noclegowni, schronisk dla bezdomnych, ogrzewalni i tymczasowych pomieszczeń (Dz.U. 2020, poz. 509, ze zm.).

Ustawa z dnia 27 września 2013 r. o pomocy państwa w nabyciu pierwszego mieszkania przez młodych ludzi (Dz.U. 2019, poz. 1116, ze zm.).

\section{Strony internetowe}

https://businessinsider.com.pl/twoje-pieniadze/prawo-i-podatki/historia-podatku-pit-w-polsce-jak-sie-zmienialy-ulgi-i-stawki/cmkpcbt.

https://innpoland.pl/165559,koniec-mieszkania-plus-gowin-bedzie-nowy-program-mieszkaniowy. https://kzn.bip.gov.pl/articles/pdf/107522.

https://mplus.pl/.

https://www.bgk.pl/aktualnosci/miliard-rocznie-dla-gmin-bgk-wspiera-budownictwo-komunalne-i-socjalne-2525/.

https://www.bgk.pl/przedsiebiorstwa/fundusze-i-programy/program-wspierania-spolecznego-budownictwa-czynszowego/.

https://www.podatki.gov.pl/pit/ulgi-odliczenia-i-zwolnienia/ulga-termomodernizacyjna/. 